\title{
EVALUATION OF HYDRO GEOCHEMISTRY OF NORTH CHENNAI COASTAL AQUIFER TO ASSESS THE GROUNDWATER SUITABILITY FOR DRINKING AND IRRIGATION PURPOSES
}

\author{
T. Siva Subramanian* and Marykutty Abraham \\ Centre for Remote Sensing and Geoinformatics, Sathyabama Institute of Science and \\ Technology, Jeppiaar Nagar, Chennai-600119. \\ *E-mail: tpshiva_mani@yahoo.com
}

\begin{abstract}
Pressure on groundwater is increasing for domestic, agricultural and industrial requirements and the water level has fallen drastically. In coastal aquifers, the extraction of groundwater by overpumping leads to seawater intrusion. The present investigation focuses on the evaluation of hydrogeochemical parameters of groundwater of North Chennai area foritssuitability for various purposes. 33 groundwater samples collected from different locations in Araniyar and Kosasthalaiyar river basin in the North East coast of Tamil Nadu were analyzed according to APHA standards. Total Hardness, Sodium Absorption Ratio, Chloride Bicarbonate Ratio, Permeability Index and Kelly's Ratio values were calculated from major ionic concentrations of $\mathrm{Na}, \mathrm{Mg}, \mathrm{Ca}, \mathrm{HCO}_{3}$ for its suitability for drinking and irrigation purposes. Based on the parameters studied it was found that groundwater in most of the locations in the study area is not good for drinking and irrigation purposes. From this study, it is inferred that groundwater is undergoing quality deterioration near coastal areas. Continuous monitoring of groundwater quality is essential in coastal areas to control saline water intrusion and mange the aquifer from further damage.
\end{abstract}

Keywords: River basin, Hydrogeochemistry, Coastal aquifer, water quality, Salinity

(C) RASĀYAN. All rights reserved

\section{INTRODUCTION}

Groundwater plays a vital role in the sub urban development of Chennai. It is the important renewable resource for domestic, agricultural and industrial purposes in the coastal areas. Rapid urban development, industrial effluents, heavy usage of agricultural fertilizers, municipal wastewater, animal wastes, landfill leakage and extensive pumping are the major reasons for water quality deterioration and saline water intrusion ${ }^{1}$.Hydrogeochemistry of groundwater is varying both laterally and vertically. There is a huge imbalance between recharge and discharge and as a result water level has fallen and the use of groundwater became non-potable. Analysis water quality is an important factor in groundwater studies. Groundwater quality is greatly influenced by geological formations, anthropogenic activities and seawater intrusion. The concentration of various dissolved salts present in groundwater depends on several factors like geological age of aquifer material, geologic features of the aquifer material, groundwater flow and contribution from recharge, physicochemical environment and presence or absence of catalytic substances and hydro geochemistry ${ }^{2}$. The chemical quality of groundwater is also influenced by nature of soils, geological formation, drainage, irrigation practices, pumping and recharge. Extensive pumping can lead to saline water entering the inland. Continuous evaluation of hydro geochemical parameters is essential to protect the coastal aquifer from saline water intrusion and further contamination ${ }^{3}$. Hencethe geochemical study of the urban coastal aquifer is necessary to assess the suitability of groundwater for various purposes. The present investigation attempts to evaluate groundwater quality in the study area and analyze its suitability for drinking and irrigation purposes.

\section{Study Area}

\section{EXPERIMENTAL}

The study area is in the coastal zone composed of a wide range of unconsolidated alluvial formation of clay, silt and sand belonging to Tertiary to Quaternary age. The study area covers $296 \mathrm{~km}$ and lies 
betweenthe northern latitude of $13^{\circ} 12^{\prime} 25.33^{\prime \prime}$ and $13^{\circ} 20^{\prime} 01.9^{\prime \prime}$ and eastern longitude of $80^{\circ} 19^{\prime} 21.51^{\prime \prime}$ and $80^{\circ} 08^{\prime} 44.85^{\prime \prime}$. Location map of the study area with sampling points is given in Fig.-1. The alluvium sediments deposited by Araniyar river basin comprises pure sand whereas the korattalaiyar river basin consists of reddish loamy sands with clay. This alluvium consists of potential aquifers known as Madras Aquifer System which provided water to industries and for domestic needs of Chennai city ${ }^{4}$.The study area consists of geomorphologic features of coastal plain, beach and beach ridges and sedimentary alluvial plain. In the study area, the unconsolidated sediments are represented by the fluvial and coastal alluvium. Bottom sediments consist of particles have been transported by water, glaciers or air from the sites of their origin in a terrestrial ecosystem and have been deposited on the floor of a lake, river or ocean $^{5}$. The land use/land covers of the study area include town, city, plantation andwaterlogged area. The temperature of the area ranges between a maximum value of $45^{\circ} \mathrm{C}$ in summer to a minimum value of $25^{\circ} \mathrm{C}$ in winter. Average annual rainfall is $1200 \mathrm{~mm}$ with maximum rainfall during North-East monsoon.

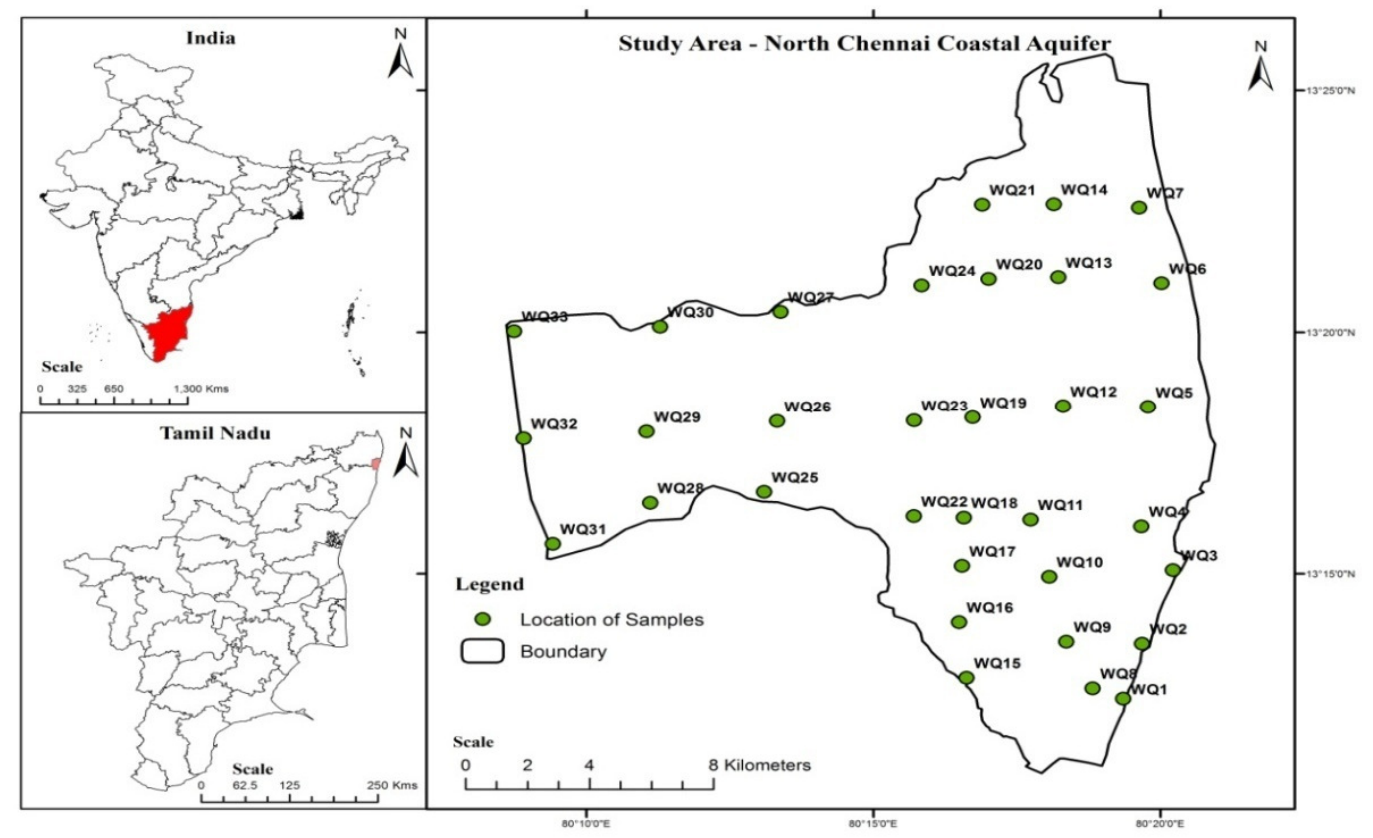

Fig.-1: Map of the Study Area showing locations of groundwater sampling

\section{Groundwater Sampling and Analysis}

A total of 33 groundwater samples were collected from 33 locations in the study area for geochemical analysis such as pH, Total Dissolved Solids, Electrical Conductivity, Bicarbonate, Calcium, Magnesium, Sodium, Chloride, Sulphate and Nitrate from dug wells and tube wells as per standard procedure. Locations of groundwater samples collected with distance from coast and elevation are given in Table-1. Groundwater samples from the study area were collected and analysed in three categories based on the location such as Type - I (Sample number 1 to 14 ) within a maximum $5 \mathrm{~km}$ from the sea coast, Type - II (Sample number 15 to 24 ) between $5 \mathrm{~km}$ to $10 \mathrm{~km}$ from sea coast and Type - III (Sample number 25 to 33) above 10 from sea coast. Laboratory Analysis was carried out as per procedure is given by APHA $(2005)^{6}$. The evaluation of hydrogeochemistry of the study area is based on WHO standard (2004) ${ }^{7}$ and Indian standard (IS: 10500, 2012) for drinking 8 .

The concentrations of Calcium, Magnesium, Sodium and Bicarbonate were used to calculate Total Hardness (TH), Sodium Absorption Ratio (SAR), Chloride Bicarbonate Ratio (CBR), Permeability Index (PI) and Kelley's Ratio (KR) as per the methods are given below to study irrigation suitability of groundwater samples. 
Total hardness of groundwater was computed by the formula ${ }^{9}$ :

$\mathrm{TH}=2.497 \mathrm{Ca}+4.115 \mathrm{Mg}$ expressed in $\mathrm{ppm}$

The Sodium Absorption Ratio was calculated using the following equation ${ }^{10}$ :

$$
\mathrm{SAR}=\frac{N a}{\sqrt{(C a}+M g) / 2}
$$

The Permeability index was calculated by the following equation ${ }^{11}$ :

$$
\mathrm{PI}=\frac{\mathrm{Na}+\sqrt{\mathrm{HCO} 3}}{\mathrm{Ca}+\mathrm{Mg}+\mathrm{Na}} \times 100
$$

The Kelly's ratio was computed using the equation given below ${ }^{12}$ :

$$
\mathrm{KR}=\frac{N a}{C a+M g} \text { all ions in epm }
$$

Groundwater quality was evaluated and suitability was assessed for drinking and irrigation purposes. The criteria used for categorization is as follows. If all the water quality parameters assessed for a sample fall within the desirable limit for drinking water standards of WHO, then the sample will be accepted in the desirable for drinking category. Similarly, if any parameter of the sample is beyond permissible limit then the sample will be considered unsuitable for drinking. If any of the parameters is only in permissible limit and no parameter is in the unsuitable category, the sample will be accepted in the permissible for drinking category. Similarly, suitability for irrigation will be made on a scale good, moderate and bad category based on parameters for irrigation water quality.

Table-1: Locations of Groundwater samples collected

\begin{tabular}{c|l|c|c|c|c}
\hline $\begin{array}{c}\text { Sample } \\
\text { No. }\end{array}$ & Location & Latitude & Longitude & $\begin{array}{c}\text { Distance } \\
\text { from the } \\
\text { coast }(\mathrm{km})\end{array}$ & $\begin{array}{c}\text { Elevation } \\
(\mathrm{Ft})\end{array}$ \\
\hline 1 & Kathivakkam & $13^{\circ} 12^{\prime} 25.33^{\prime \prime}$ & $80^{\circ} 19^{\prime} 21.51^{\prime \prime}$ & 0.06 & 18 \\
\hline 2 & Tulsikuppam & $13^{\circ} 13^{\prime} 33.69^{\prime \prime}$ & $80^{\circ} 19^{\prime} 40.57^{\prime \prime}$ & 0.20 & 23 \\
\hline 3 & Mugathuvaram & $13^{\circ} 15^{\prime} 05.61^{\prime \prime}$ & $80^{\circ} 20^{\prime} 13.86^{\prime \prime}$ & 0.25 & 2 \\
\hline 4 & Puzhuthivakkam & $13^{\circ} 15^{\prime} 59.7^{\prime \prime}$ & $80^{\circ} 19^{\prime} 40.54^{\prime \prime}$ & 1.10 & 17 \\
\hline 5 & Kattupalli & $13^{\circ} 18^{\prime} 28.75^{\prime \prime}$ & $80^{\circ} 19^{\prime} 47.07^{\prime \prime}$ & 1.90 & 21 \\
\hline 6 & Karungali & $13^{\circ} 21^{\prime} 00.89^{\prime \prime}$ & $80^{\circ} 20^{\prime} 01.59^{\prime \prime}$ & 0.90 & 23 \\
\hline 7 & Thangalperumbalam & $13^{\circ} 22^{\prime} 35.09^{\prime \prime}$ & $80^{\circ} 19^{\prime} 38.23^{\prime \prime}$ & 0.90 & 12 \\
\hline 8 & Nehru nagar & $13^{\circ} 12^{\prime} 38.23^{\prime \prime}$ & $80^{\circ} 18^{\prime} 49.23^{\prime \prime}$ & 1.10 & 11 \\
\hline 9 & NTECL ash dyke & $13^{\circ} 13^{\prime} 36.12^{\prime \prime}$ & $80^{\circ} 18^{\prime} 22.00^{\prime \prime}$ & 2.60 & 8 \\
\hline 10 & Athipattupudhunagar & $13^{\circ} 14^{\prime} 56.55^{\prime \prime}$ & $80^{\circ} 18^{\prime} 04.1^{\prime \prime}$ & 4.00 & 12 \\
\hline 11 & Athipattu & $13^{\circ} 16^{\prime} 07.05^{\prime \prime}$ & $80^{\circ} 17^{\prime} 44.66^{\prime \prime}$ & 4.60 & 11 \\
\hline 12 & Ooranambedu & $13^{\circ} 18^{\prime} 28.5^{\prime \prime}$ & $80^{\circ} 18^{\prime} 18.67^{\prime \prime}$ & 4.60 & 13 \\
\hline 13 & Kadapakkam & $13^{\circ} 21^{\prime} 08.67^{\prime \prime}$ & $80^{\circ} 18^{\prime} 13.67^{\prime \prime}$ & 4.90 & 16 \\
\hline 14 & Sirupazhaverkadu & $13^{\circ} 22^{\prime} 39.37^{\prime \prime}$ & $80^{\circ} 18^{\prime} 08.85^{\prime \prime}$ & 3.50 & 15 \\
\hline 15 & Manali new town & $13^{\circ} 12^{\prime} 51.14^{\prime \prime}$ & $80^{\circ} 16^{\prime} 37.81^{\prime \prime}$ & 5.30 & 16 \\
\hline 16 & Vallur & $13^{\circ} 14^{\prime} 00.42^{\prime \prime}$ & $80^{\circ} 16^{\prime} 30.22^{\prime \prime}$ & 6.00 & 19 \\
\hline 17 & Vallur camp & $13^{\circ} 15^{\prime} 09.78^{\prime \prime}$ & $80^{\circ} 16^{\prime} 32.82^{\prime \prime}$ & 7.00 & 20 \\
\hline 18 & Nandiyambakkam - H & $13^{\circ} 16^{\prime} 09.75^{\prime \prime}$ & $80^{\circ} 16^{\prime} 34.8^{\prime \prime}$ & 6.70 & 20 \\
\hline 19 & Neidavoyal & $13^{\circ} 18^{\prime} 14.45^{\prime \prime}$ & $80^{\circ} 16^{\prime} 44.21^{\prime \prime}$ & 7.40 & 28 \\
\hline
\end{tabular}


RASĀYAN J. Chem.

Vol. 11 | No. 2 |806 - 818 | April - June | 2018

\begin{tabular}{l|l|c|c|c|c}
\hline 20 & Kattur & $1^{\circ} 21^{\prime} 06.61^{\prime \prime}$ & $80^{\circ} 17^{\prime} 00.82^{\prime \prime}$ & 6.30 & 16 \\
\hline 21 & Thattaimanji & $13^{\circ} 22^{\prime} 38.74^{\prime \prime}$ & $80^{\circ} 16^{\prime} 53.8^{\prime \prime}$ & 5.80 & 17 \\
\hline 22 & Minjur & $13^{\circ} 16^{\prime} 11.67^{\prime \prime}$ & $80^{\circ} 15^{\prime} 42.54^{\prime \prime}$ & 8.30 & 26 \\
\hline 23 & Maratoor / Kalpakkam & $13^{\circ} 18^{\prime} 10.97^{\prime \prime}$ & $80^{\circ} 15^{\prime} 42.87^{\prime \prime}$ & 9.20 & 30 \\
\hline 24 & Somanjeri & $13^{\circ} 20^{\prime} 58.64^{\prime \prime}$ & $80^{\circ} 15^{\prime} 50.89^{\prime \prime}$ & 8.50 & 19 \\
\hline 25 & Vannipakkam & $1^{\circ} 16^{\prime} 41.52^{\prime \prime}$ & $80^{\circ} 13^{\prime} 06.13^{\prime \prime}$ & 13.70 & 43 \\
\hline 26 & Anuppampattu & $13^{\circ} 18^{\prime} 09.73^{\prime \prime}$ & $80^{\circ} 13^{\prime} 19.61^{\prime \prime}$ & 13.50 & 28 \\
\hline 27 & Lingapayampettai & $13^{\circ} 20^{\prime} 26.29^{\prime \prime}$ & $80^{\circ} 13^{\prime} 23.33^{\prime \prime}$ & 13.00 & 29 \\
\hline 28 & Jaganathapuram & $1^{\circ} 16^{\prime} 28.38^{\prime \prime}$ & $80^{\circ} 11^{\prime} 07.27^{\prime \prime}$ & 16.50 & 40 \\
\hline 29 & Amoor & $13^{\circ} 17^{\prime} 56.76^{\prime \prime}$ & $80^{\circ} 11^{\prime} 03.29^{\prime \prime}$ & 18.70 & 52 \\
\hline 30 & Ponneri & $1^{\circ} 20^{\prime} 07.51^{\prime \prime}$ & $80^{\circ} 11^{\prime} 17.42^{\prime \prime}$ & 16.90 & 37 \\
\hline 31 & $\begin{array}{l}\text { Janappanchathiramkoot } \\
\text { road }\end{array}$ & $1^{\circ} 15^{\prime} 37.23^{\prime \prime}$ & $80^{\circ} 09^{\prime} 25.37^{\prime \prime}$ & 19.50 & 53 \\
\hline 33 & Thatchoorkoot road & $1^{\circ} 17^{\prime} 48.08^{\prime \prime}$ & $80^{\circ} 08^{\prime} 54.62^{\prime \prime}$ & 21.60 & 56 \\
\hline
\end{tabular}

\section{RESULTS AND DISCUSSION}

Physicochemical characters of groundwater samples such as $\mathrm{pH}$, Total Dissolved Solids (TDS) and Electrical Conductivity (EC) were measured in the field using portable meters. The in situ water tests such as $\mathrm{pH}$, TDS and EC provide useful preliminary information about the water quality of water samples. The groundwater samples were analyzed in the laboratory for Bicarbonate $\left(\mathrm{HCO}_{3}\right)$, Calcium $(\mathrm{Ca})$, Magnesium $(\mathrm{Mg})$, Sodium $(\mathrm{Na})$, Chloride $(\mathrm{Cl})$, Sulphate $\left(\mathrm{SO}_{4}\right)$ and Nitrate $\left(\mathrm{NO}_{3}\right)$ as per American Public Health Association (APHA 2005) methods. Groundwater quality of the study area with locations is presented in table - 2. The analysis shows groundwater quality parameters of the study area vary with respect to distance from sea coast and geologic formation.

Table-2: Groundwater quality parameters of the study area

\begin{tabular}{c|c|c|c|c|c|c|c|c|c|c|c}
\hline $\begin{array}{c}\text { Sample } \\
\text { Number }\end{array}$ & $\begin{array}{c}\text { Location } \\
\text { (Village name) }\end{array}$ & $\mathrm{pH}$ & $\mathrm{TDS}$ & $\mathrm{EC}$ & $\mathrm{HCO}_{3}$ & $\mathrm{Ca}$ & $\mathrm{Mg}$ & $\mathrm{Na}$ & $\mathrm{Cl}$ & $\mathrm{SO}_{4}$ & $\mathrm{NO}_{3}$ \\
\hline 1 & Kathivakkam & 7.26 & 685 & 1675 & 452 & 96 & 28.1 & 376 & 239 & 38 & 14.2 \\
\hline 2 & Tulsikuppam & 6.89 & 532 & 2248 & 124 & 34 & 35.3 & 169 & 336 & 84 & 21.6 \\
\hline 3 & Mugathuvaram & 7.15 & 897 & 1722 & 99 & 22 & 23.7 & 226 & 425 & 96 & 16.8 \\
\hline 4 & Puzhuthivakkam & 7 & 1966 & 3530 & 460 & 130 & 166 & 324 & 874 & 214 & 0 \\
\hline 5 & Kattupalli & 7.25 & 620 & 885 & 178 & 52 & 13 & 144 & 130 & 18 & 9 \\
\hline 6 & Karungali & 8.7 & 956 & 1140 & 289 & 56 & 64 & 200 & 201 & 166 & 7 \\
\hline 7 & Thangalperumbalam & 8.7 & 1381 & 2250 & 356 & 22 & 20 & 474 & 371 & 180 & 3 \\
\hline 8 & Nehru nagar & 7.45 & 1030 & 1430 & 210 & 28 & 22 & 84 & 199 & 164 & 1.22 \\
\hline 9 & NTECL ash dyke & 7.62 & 1550 & 2320 & 432 & 82 & 52 & 373 & 446 & 436 & 2.48 \\
\hline 10 & Athipattupudhunagar & 7.15 & 647 & 915 & 112 & 22 & 18 & 56 & 140 & 60 & 0.4 \\
\hline 11 & Athipattu & 7.2 & 369 & 521 & 96 & 14 & 12 & 64 & 156 & 15 & 0.8 \\
\hline 12 & Ooranambedu & 6.4 & 741 & 1270 & 307 & 28 & 41 & 142 & 215 & 94 & 0 \\
\hline 13 & Kadapakkam & 7.7 & 2674 & 5000 & 185 & 122 & 197 & 589 & 1392 & 267 & 3 \\
\hline 14 & Sirupazhaverkadu & 6.99 & 647 & 1964 & 325 & 48 & 21.6 & 394 & 356 & 66 & 15.2 \\
\hline 15 & Manali new town & 6.85 & 925 & 1887 & 205 & 136 & 28.4 & 365 & 471 & 128 & 26.2 \\
\hline
\end{tabular}


RASĀYAN J. Chem.

Vol. 11 | No. 2 |806-818 | April - June | 2018

\begin{tabular}{|c|c|c|c|c|c|c|c|c|c|c|c|}
\hline 16 & Vallur & 7.61 & 932 & 1102 & 450 & 142 & 11.4 & 43 & 331 & 56 & 10.4 \\
\hline 17 & Vallur camp & 7.83 & 982.4 & 2468 & 158 & 59 & 24.6 & 69 & 316 & 42 & 9.4 \\
\hline 18 & $\begin{array}{c}\text { Nandiyambakkam - } \\
\mathrm{H}\end{array}$ & 7.21 & 782.2 & 1219 & 275 & 25 & 12.4 & 152 & 221 & 31 & 12.2 \\
\hline 19 & Neidavoyal & 8.5 & 1079 & 2050 & 136 & 102 & 90 & 154 & 512 & 94 & 1 \\
\hline 20 & Kattur & 8.4 & 2108 & 3160 & 356 & 46 & 122 & 566 & 895 & 190 & 15 \\
\hline 21 & Thattaimanji & 7.32 & 546 & 1105 & 326 & 25 & 10.4 & 526 & 246 & 12 & 12.4 \\
\hline 22 & Minjur & 7.22 & 1220 & 1848 & 258 & 22 & 12 & 134 & 236 & 180 & 0.84 \\
\hline 23 & $\begin{array}{l}\text { Maratoor / } \\
\text { Kalpakkam }\end{array}$ & 7.18 & 1449 & 2070 & 327 & 150 & 48 & 164 & 422 & 253 & 20 \\
\hline 24 & Somanjeri & 8.2 & 984 & 1720 & 307 & 78 & 44 & 225 & 357 & 106 & 3 \\
\hline 25 & Vannipakkam & 8 & 540 & 1000 & 289 & 32 & 65 & 76 & 147 & 70 & 1 \\
\hline 26 & Anuppampattu & 7.41 & 1220 & 1712 & 282 & 38 & 22 & 194 & 358 & 150 & 1.6 \\
\hline 27 & Lingapayampettai & 7.28 & 893 & 1275 & 292 & 88 & 26 & 208 & 200 & 72 & 25 \\
\hline 28 & Jaganathapuram & 7.28 & 1720 & 2440 & 484 & 44 & 28 & 386 & 428 & 456 & 2.64 \\
\hline 29 & Amoor & 7.23 & 1360 & 1922 & 344 & 25 & 14 & 284 & 468 & 284 & 1.22 \\
\hline 30 & Ponneri & 7.7 & 338 & 600 & 130 & 54 & 20 & 16 & 55 & 31 & 12 \\
\hline 31 & $\begin{array}{c}\text { Janappanchathiramko } \\
\text { ot road }\end{array}$ & 6.55 & 297 & 394 & 378 & 58 & 40 & 58 & 184 & 78 & 1.62 \\
\hline 32 & Thatchoorkoot road & 6.9 & 1170 & 1661 & 329 & 32 & 34 & 258 & 454 & 130 & 1.22 \\
\hline 33 & Pudhuvoyal & 7.3 & 703 & 992 & 160 & 28 & 12 & 76 & 166 & 38 & 0.1 \\
\hline
\end{tabular}

All units except $\mathrm{pH}$ and $\mathrm{EC}$ are in $\mathrm{mg} / \mathrm{l}$.

Electrical Conductivity (EC) is in $\mu \mathrm{s} / \mathrm{cm}$

Drinking Water Quality

The quality of groundwater samples was compared with the desirable and permissible limits for drinking water of WHO (2004) and Indian Standard (IS 10500: 2012) and are given in Table-3.

Table-3: Quality of groundwater samples based on WHO and Indian Standard

\begin{tabular}{|c|c|c|c|c|c|c|c|c|}
\hline \multirow[t]{2}{*}{ S. No. } & \multirow[t]{2}{*}{ Parameter } & \multicolumn{2}{|c|}{ WHO (2004) } & \multicolumn{2}{|c|}{$\begin{array}{l}\text { Indian Standards } \\
\text { ( IS } 10500: 2012 \text { ) }\end{array}$} & \multicolumn{3}{|c|}{$\begin{array}{l}\text { Quality ofgroundwater samples of the } \\
\text { study area }\end{array}$} \\
\hline & & $\begin{array}{c}\text { Desirabl } \\
\mathrm{e} \\
\text { limit }\end{array}$ & $\begin{array}{l}\text { Permissible } \\
\text { limit }\end{array}$ & $\begin{array}{c}\text { Desirable } \\
\text { limit }\end{array}$ & $\begin{array}{l}\text { Permissible } \\
\text { limit }\end{array}$ & $\begin{array}{l}\text { Minimum } \\
\text { value }\end{array}$ & $\begin{array}{l}\text { Maximu } \\
\text { m value }\end{array}$ & $\begin{array}{c}\text { No. of } \\
\text { samples } \\
\text { and } \\
\text { percentagei } \\
\mathrm{n} \\
\text { permissible } \\
\text { limit* }\end{array}$ \\
\hline 1 & $\mathrm{pH}$ & $6.5-8.5$ & $6.5-8.5$ & $6.5-8.5$ & $6.5-8.5$ & 6.4 & 8.7 & $30(91 \%)$ \\
\hline 2 & $\begin{array}{c}\text { Total } \\
\text { Dissolved } \\
\text { Solids }\end{array}$ & 500 & 1500 & 500 & 2000 & 338 & 2674 & $28(85 \%)$ \\
\hline 3 & $\begin{array}{c}\text { Electrical } \\
\text { Conductivity }\end{array}$ & 750 & 2300 & 750 & 3000 & 521 & 5000 & $27(82 \%)$ \\
\hline 4 & Bi Carbonate & - & 300 & - & - & 96 & 484 & $18(55 \%)$ \\
\hline 5 & Calcium & 75 & 200 & 75 & 200 & 14 & 150 & $33(100 \%)$ \\
\hline 6 & Magnesium & 30 & 150 & 30 & 100 & 10.4 & 197 & $31(94 \%)$ \\
\hline
\end{tabular}


RASĀYAN J. Chem.

Vol. 11 | No. 2 |806 - 818 | April - June | 2018

\begin{tabular}{c|c|c|c|c|c|c|c|c}
7 & Sodium & - & 200 & 30 & 100 & 16 & 589 & $21(64 \%)$ \\
\hline 8 & Chloride & 200 & 600 & 250 & 1000 & 55 & 1392 & $29(88 \%)$ \\
\hline 9 & Sulphate & 200 & 400 & 200 & 400 & 12 & 456 & $32(97 \%)$ \\
\hline 10 & Nitrate & 45 & 45 & 45 & 45 & 0 & 26.2 & $33(100 \%)$ \\
\hline
\end{tabular}

All units except $\mathrm{pH}$ and $\mathrm{EC}$ are in $\mathrm{mg} / \mathrm{l}$

Electrical Conductivity (EC) is in $\mu \mathrm{s} / \mathrm{cm}$

*permissible limit as per WHO (2004)

\section{pH}

Hydrogen ion concentration $(\mathrm{pH})$ is the measure of the acidity or alkalinity of a solution. During the present investigation, $\mathrm{pH}$ values of the samples ranged between 6.4 and 8.7 with an average value 7.44. The $\mathrm{pH}$ value as low as 6.4 was recorded in Oornambeduvillage which shows slightly acidic nature and the highest value was found in Karungali and Thangalperumbalam with a value of 8.7 which indicate that the water is slightly alkaline in nature in these areas. The central part of the study area has higher $\mathrm{pH}$ value. Thus the water quality varies from slightly acidic to alkaline.Groundwater classification based on $\mathrm{pH}$ value shows that 30 groundwater samples are in the category of desirable for drinking which is 91 percent of the total samples analyzed(Table-3). 9 percent of the samples i.e. three samples are coming in the category of unsuitable for drinking.

\section{The total Dissolved Solids concentration}

Total Dissolved Solids (TDS) indicate the presence of various types of minerals present in water. It composed of mainly carbonates, bicarbonates, calcium, magnesium, chlorides, sulphate, phosphate, sodium, potassium and silica. TDS values are ranging from $338 \mathrm{mg} / \mathrm{l}$ to $2674 \mathrm{mg} / \mathrm{l}$ with an average value $1028.62 \mathrm{mg} / \mathrm{l}$. The TDS value as low as $338 \mathrm{mg} / \mathrm{l}$ was recorded in Ponneri and the highest was found in Kadapakkam with a value of $2674 \mathrm{mg} / \mathrm{l}$. This also indicates that the groundwater of the Eastern part of the study area which is nearer to the coast is saline in nature. Groundwater classification based on TDS, value shows that 28 groundwater samples i.e. 85 percent of the samples analyzed falls in the category of desirable for drinking (Table-3). 15 percent of the samples i.e. five samples are in the category of unsuitable for drinking.

\section{Electrical Conductivity Concentration}

Electrical conductivity (EC) is a measure of electrical conductance of the water which indicates the presence of salts in water. In the present study, EC values range from $521 \mu \mathrm{s} / \mathrm{cm}$ to $5000 \mu \mathrm{s} / \mathrm{cm}$ with an average value $1742.27 \mu \mathrm{s} / \mathrm{cm}$. The lowest EC value of $521 \mu \mathrm{s} / \mathrm{cm}$ was obtained in Athipattu and the highest value of $5000 \mathrm{mg} / \mathrm{l}$ was found in Kadapakkam. The groundwater of Kadapakkam and nearby areas indicates seawater intrusion. Eastern part of the study area has high EC values due to seawater intrusion.EC value is high in some locations due to saline sources, mineral dissolution and influx of pollutants from anthropogenic activities ${ }^{13}$. Groundwater classification based on EC shows that 27 groundwater samples i.e. 82 percent of the samples analyzed come in the category of desirable for drinking (Table-3). Six samples i.e. 18 percent of the samples come in the category of unsuitable for drinking.

\section{Bicarbonate Concentration}

Bicarbonate $\left(\mathrm{HCO}_{3}\right)$ concentration indicates the weathering processes of carbonate rocks. The Bicarbonate concentration ranges between $96 \mathrm{mg} / \mathrm{l}$ to $484 \mathrm{mg} / \mathrm{l}$ for the study area with an average value of $276.09 \mathrm{mg} / \mathrm{l}$. The Bicarbonate concentration is very high in Jaganathapuram and very low in Athipattu area. Bicarbonate concentration is high in some locations which are mainly due to the dissolution of carbonate minerals and agricultural return flow. Groundwater classification based on $\mathrm{HCO}_{3}$, value shows that 18 groundwater samples i.e. 55 percent of the samples analyzed falls in the category of permissible for drinking (Table-3). 45 percent of the samples i.e. 15 samples are falling into the category of unsuitable for drinking. 


\section{Calcium Concentration}

Calcium (Ca) concentration values vary from $14 \mathrm{mg} / \mathrm{l}$ to $150 \mathrm{mg} / \mathrm{l}$ with an average value of $58.79 \mathrm{mg} / \mathrm{l}$. The Calcium concentration is very high in Kalpakkam and very low in Athipattu area. Calcium concentration may be developed from the dissolution of calcium carbonate materials and calcium rich rocks. Calcium and magnesium ions create hardness of groundwater. Groundwater classification based on Ca concentration reveals that all the groundwater samples tested falls into the category of desirable for drinking (Table-3).

\section{Magnesium Concentration}

Magnesium (Mg) concentration ranges from $10.4 \mathrm{mg} / \mathrm{l}$ to $197 \mathrm{mg} / \mathrm{l}$ with the average value of $41.75 \mathrm{mg} / \mathrm{l}$. Magnesium concentration is very high in Kadapakkam and very low in Thattimanji. Magnesium also formed from carbonate rocks and all magnesium rich rocks.

Groundwater classification based on $\mathrm{Mg}$, value shows that 31 groundwater samples i.e. 94 percent of the samples tested falls in the category of permissible for drinking (Table-3). Two samples i.e. 6 percent of the samples are falling into the category of unsuitable for drinking.

\section{SodiumConcentration}

Sodium (Na) concentration ranges from $16 \mathrm{mg} / \mathrm{l}$ to $589 \mathrm{mg} / \mathrm{l}$ with the average value of $229.36 \mathrm{mg} / \mathrm{l}$. Sodium concentration value is very high in Kadapakkam and very low in Ponneri. Sodium concentration plays a vital role in deciding the suitability of water for irrigation purpose, because sodium can increase the hardness of soil and reduces the permeability ${ }^{14}$.Groundwater classification based on $\mathrm{Na}$, value shows that 21 groundwater samples i.e. 64 percent of the samples analyzed is occurring in the group permissible for drinking (Table-3). Twelve samples i.e. 36 percent of the samples are in the category of unsuitable for drinking.

\section{Chloride Concentration}

The concentration of chloride $(\mathrm{Cl})$ ranges between $55 \mathrm{mg} / \mathrm{l}$ and $1392 \mathrm{mg} / \mathrm{l}$ with an average value of 362.03 $\mathrm{mg} / \mathrm{l}$. The chloride concentration is very high in Kadapakkam and very low in Ponneri. If the concentration of chloride is above $250 \mathrm{mg} / 1$, the saltiness can be recognized. The sources of chloride concentration in groundwater samples are geological formations, wastage and sewage discharges, agricultural fertilizers, industrial effluents and sea water intrusion. Groundwater classification based on $\mathrm{Cl}$, value shows that 29 groundwater samples i.e. 88 percent of the samples analyzed falls in the category of Permissible for drinking are given in Table-3. Four samples i.e. 12 percent of the samples are falling into the category of unsuitable for drinking.

\section{SulphateConcentration}

The sulphate $\left(\mathrm{SO}_{4}\right)$ concentration in the study area is ranging from $12 \mathrm{mg} / \mathrm{l}$ to $456 \mathrm{mg} / \mathrm{l}$ and the average value is $130.27 \mathrm{mg} / \mathrm{l}$. Sulphate concentration is very high in Jaganathapuram and low in Thattaimanji area. Sulphate is dissolved mainly from sedimentary rocks containing gypsum, iron sulfides and due to some industrial wastes. High concentration of $\mathrm{SO}_{4}$ in drinking water is toxic in nature. Groundwater classification based on $\mathrm{SO}_{4}$ concentration shows that of the 33 groundwater samples analyzed 32 samples i.e. 97 percent is in the category of desirable for drinking are shown in Table-3.

\section{Nitrate Concentration}

The nitrate $\left(\mathrm{NO}_{3}\right)$ concentration ranges from 0 to $26.2 \mathrm{mg} / \mathrm{lwith}$ an average value of $7.62 \mathrm{mg} / \mathrm{l}$. The nitrate concentration is very high in Manali new town and low in Ooranambedu area. The concentration of nitrate is formed from the biosphere and chemical reaction of soil bacteria to ammonium ${ }^{15}$. High concentration of $\mathrm{NO}_{3}$ in drinking water is toxic to life. Groundwater classification based on $\mathrm{NO}_{3}$, value shows that all 33 groundwater samples analyzed are in desirable for drinking category are shown in Table-3. 
From the study it is clear that quality of groundwater improves as the distance from coast increases. Groundwater of Kadapakkam village has the highest concentration of most of water quality parameters (TDS, EC, $\mathrm{Mg}, \mathrm{Na}$ and $\mathrm{Cl}$ ) due to saline water intrusion. Kadapakkam is $4.90 \mathrm{~km}$ from the coast. Ponneri village shows the best water quality which is $16.90 \mathrm{~km}$ away from the coast. Also, Ponneri is near to Araniyar river which can further dilute the concentration of pollution load. Groundwater quality in the eastern side of the study area is exceeding the permissible limits prescribed by WHO (2004) and Indian Standard (IS: 10500:2012) for domestic purposes.

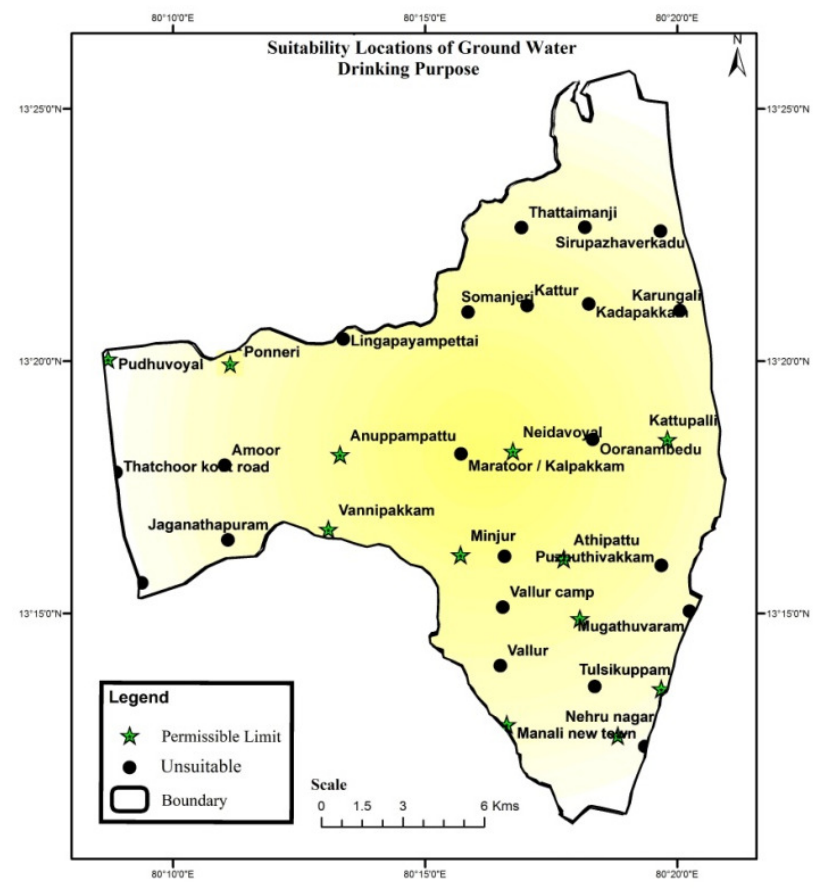

Fig.-2:Groundwater locations of permissible limit and unsuitable for drinking purpose

Based on the parameters studied, groundwater locations suitable for drinking purpose in the study areais given in Fig.-2. Interpolated map of areas is showing locations of villages which is in permissible limit and unsuitable for drinking only and no sample is available in the desirable limit as per WHO standard.The villages with groundwater quality within the permissible limit in the study area are Tulsikuppam, Kattupalli, Nehru Nagar, Athipattupudhunagar, Athipattu, Manali new town, Neidavoyal, Minjur, Vannipakkam, Anuppampattu, Ponneri and Pudhuvoyal. Other villages come under the unsuitable category. Groundwater quality in the northern part of the study area is unsuitable for drinking. In the eastern sidethough the influence of sea is there, dilution is taking place due to the presence of Bukingham canal and Pulicat Lake near the eastern boundary of the study area.

\section{Irrigation Water Quality}

Total Hardness (TH), Sodium Absorption Ratio (SAR), Chloride Bicarbonate Ratio (CBR), Permeability Index (PI) and Kelly's Ratio (KR) values for various locations in the study area calculated from major ionic concentrations of $\mathrm{Na}, \mathrm{Mg}, \mathrm{Ca}, \mathrm{HCO}_{3}$ are given in Table- 4 .

\section{Total Hardness}

Total hardness of water samples shows the presence of calcium and magnesium in groundwater. The hardness of water is formed by dissolution of $\mathrm{CO}_{2}$, which is released by bacterial action in the soil and also from percolating rainwater. Total Hardness for the study area varies between $84.338 \mathrm{ppm}$ and $1115.289 \mathrm{ppm}$ with an average value of $318.613 \mathrm{ppm}$. The lowest value of total hardness $84.338 \mathrm{ppm}$ is obtained in Athipattu and highest value of 1115.289 ppm is obtained in Kadapakkam. According to WHO 
standards, total hardness of samples $2,3,5,7,8,10,11,12,14,17,18,21,22,26,28,29,32$ and 33 comes in excellent category (55), samples 1, 24, 25, 27 and 31 comes in good category (15\%), samples 6, 9, 15 and 16 comes in medium category (12\%) and sample 23 comes in bad category (3\%). Total Hardness of samples 4, 13, 19 and 20 are of very bad category (12\%). Total Hardness of most of the locations in the study area falls within excellent to good category.

\section{Sodium Absorption Ratio}

Sodium Adsorption Ratio (SAR) indicates the sodium/alkali contents. SAR is the proportion of sodium $(\mathrm{Na})$ to calcium $(\mathrm{Ca})$ and magnesium $(\mathrm{Mg})$ ions in a sample. Sodium Absorption Ratio varies from 2.630 $\mathrm{mg} / \mathrm{l}$ to $125.026 \mathrm{mg} / \mathrm{l}$ with an average value of $35.810 \mathrm{mg} / \mathrm{l}$. The lowest value of SAR $2.630 \mathrm{mg} / \mathrm{l}$ is calculated in Ponneri and highest value of $125.026 \mathrm{mg} / \mathrm{l}$ is obtained in Thattaimanji. The classification of Sodium Absorption Ratio of samples 16, 30 and 31 falls under the category of low sodium hazard zone and is in the excellent category (9\%). SAR of samples 8,10,11,17,19,23,25 and 33 falls in good category (24\%). SAR of samples 5, 6 and 12 falls in medium hazard category (9\%). SAR of samples 1, 2, 3, 4, 7, $9,13,14,15,18,20,21,22,24,26,27,28,29$ and 32 falls under the category of high sodium hazards zone and is in bad category (58\%). If irrigation water is high in sodium and low in calcium, the cationexchange complex becomes saturated with sodium ${ }^{16}$. This reaction can destroy the clay particles and the soil structure. High sodium content in the study area will require special soil management.

Table-4: Calculated values of Total Hardness, Sodium Absorption Ratio, Chloride Bicarbonate Ratio, Permeability Index and Kelly's Ratio

\begin{tabular}{c|l|c|c|c|c|c}
\hline S. No. & \multicolumn{1}{c}{$\begin{array}{c}\text { Location } \\
\text { (Village name) }\end{array}$} & $\begin{array}{c}\text { Total } \\
\text { Hardness } \\
(\mathrm{ppm})\end{array}$ & $\begin{array}{c}\text { Sodium } \\
\text { Absorption Ratio } \\
(\mathrm{meq} / \mathrm{l})\end{array}$ & $\begin{array}{c}\text { Chloride Bi } \\
\text { Carbonate } \\
\text { Ratio }\end{array}$ & $\begin{array}{c}\text { Permeability } \\
\text { Index }\end{array}$ & $\begin{array}{c}\text { Kelly's } \\
\text { Ratio }\end{array}$ \\
\hline 1 & Kathivakkam & 355.344 & 47.733 & 0.529 & 79.436 & 3.030 \\
\hline 2 & Tulsikuppam & 230.158 & 28.710 & 2.710 & 75.592 & 2.439 \\
\hline 3 & Mugathuvaram & 152.460 & 47.279 & 4.293 & 86.842 & 4.945 \\
\hline 4 & Puzhuthivakkam & 1007.700 & 26.633 & 1.900 & 55.717 & 1.095 \\
\hline 5 & Kattupalli & 183.339 & 25.259 & 0.730 & 75.283 & 2.215 \\
\hline 6 & Karungali & 403.192 & 25.820 & 0.696 & 67.813 & 1.667 \\
\hline 7 & Thangalperumbalam & 137.234 & 103.435 & 1.042 & 95.517 & 11.286 \\
\hline 8 & Nehru nagar & 160.446 & 16.800 & 0.948 & 73.501 & 1.680 \\
\hline 9 & NTECL ash dyke & 418.734 & 45.569 & 1.032 & 77.670 & 2.784 \\
\hline 10 & Athipattupudhunagar & 129.004 & 12.522 & 1.250 & 69.357 & 1.400 \\
\hline 11 & Athipattu & 84.338 & 17.750 & 1.625 & 81.998 & 2.462 \\
\hline 12 & Ooranambedu & 238.631 & 24.176 & 0.700 & 75.603 & 2.058 \\
\hline 13 & Kadapakkam & 1115.289 & 46.637 & 7.524 & 66.366 & 1.846 \\
\hline 14 & Sirupazhaverkadu & 208.740 & 66.789 & 1.095 & 88.876 & 5.661 \\
\hline 15 & Manali new town & 456.458 & 40.258 & 2.298 & 71.651 & 2.220 \\
\hline 16 & Vallur & 401.485 & 4.910 & 0.736 & 32.695 & 0.280 \\
\hline 17 & Vallur camp & 248.552 & 10.672 & 2.000 & 53.453 & 0.825 \\
\hline 18 & Nandiyambakkam $-\mathrm{H}$ & 113.451 & 35.150 & 0.804 & 89.009 & 4.064 \\
\hline 19 & Neidavoyal & 625.044 & 15.718 & 3.765 & 47.879 & 0.802 \\
\hline 20 & Kattur & 616.892 & 61.756 & 2.514 & 79.682 & 3.369 \\
\hline & & & & &
\end{tabular}


RASĀYAN J. Chem.

Vol. 11 | No. 2 |806 - 818 | April - June | 2018

\begin{tabular}{l|l|c|c|c|c|c}
\hline 21 & Thattaimanji & 105.221 & 125.026 & 0.755 & 96.910 & 14.859 \\
\hline 22 & Minjur & 104.314 & 32.500 & 0.915 & 89.323 & 3.941 \\
\hline 23 & Maratoor / Kalpakkam & 572.070 & 16.483 & 1.291 & 50.299 & 0.828 \\
\hline 24 & Somanjeri & 375.826 & 28.808 & 1.163 & 69.891 & 1.844 \\
\hline 25 & Vannipakkam & 347.379 & 10.913 & 0.509 & 53.757 & 0.784 \\
\hline 26 & Anuppampattu & 185.416 & 35.419 & 1.270 & 82.989 & 3.233 \\
\hline 27 & Lingapayampettai & 326.726 & 27.550 & 0.685 & 69.903 & 1.825 \\
\hline 28 & Jaganathapuram & 225.088 & 64.333 & 0.884 & 89.083 & 5.361 \\
\hline 29 & Amoor & 120.035 & 64.313 & 1.360 & 93.668 & 7.282 \\
\hline 30 & Ponneri & 217.138 & 2.630 & 0.423 & 30.446 & 0.216 \\
\hline 31 & Janappanchathiramkoot & 309.426 & 8.286 & 0.487 & 49.642 & 0.592 \\
\hline 32 & Thaad & 219.814 & 44.912 & 1.380 & 85.228 & 3.909 \\
\hline 33 & Pudhuvoyal & 119.296 & 16.994 & 1.038 & 76.422 & 1.900 \\
\hline
\end{tabular}

\section{Chloride Bi Carbonate Ratio}

The chloride bicarbonate ratio $(\mathrm{CBR})$ of above 2 in groundwater indicates that the water is highly saline and can be due to saline water ingress ${ }^{17}$.For the study areaCBR varies from 0.423 to 7.524 with an average value of 1.526. The lowest value of CBR 0.423 was obtained in Ponneri and highest value 7.524 was obtained in Kadapakkam. The CBR of groundwater samples 1, 4, 5, 6, 7, 8, 9, 10, 11, 12, 16, 18, 21, $22,23,24,25,26,27,28,29,30,31,32$ and $33(79 \%)$ is below 2, which indicates that the water is of low salinity and the CBR of groundwater samples 2, 3, 13, 15, 17, 19 and 20 (21\%) is above 2, which indicates that the water has high salinity.

\section{Permeability index}

The Permeability index (PI) is an important measure to assess the suitability of groundwater for irrigation. Long-term use of irrigation water affected by $\mathrm{Na}, \mathrm{Ca}, \mathrm{Mg}$ and $\mathrm{HCO}_{3}$ is the major cause of soil permeability ${ }^{18}$. PI of the study area varied from 30.466 to 96.910 with an average value of 72.167 . The lowest value of PI, 30.466 was obtained in Ponneri and highest value of Permeability Index, 96.910 was obtained in Thattaimanji. According to permeability indices the groundwater samples may be divided into Class I (PI > 75\%), Class II (PI ranges from 25\% to 75\%) and Class III (PI ranges below 25\%). According to the Permeability Index values, 55\% of the samples $(1,2,3,5,7,9,11,12,14,18,20,21,22,26,28$, 29, 32 and 33) come under Class I and the remaining $45 \%$ of the samples $(4,6,8,10,13,15,16,17,19$, $23,24,25,27,30$ and 31) come under the class II category. Groundwater in the majority of the areas is in good to moderate category for irrigation purpose as per permeability index.

\section{Kelly's Ratio}

Kelly's ratio (KR) above 1 in groundwater indicate sodium problem for irrigation and the groundwater is considered unsuitable for irrigation ${ }^{19}$. Kelly's Ratio of the samples in the study area varied from 0.216 to 14.859 with an average value of 3.112. The lowest value of Kelly's Ratio of 0.216 was obtained in Ponneri and the highest value of 14.859 in Thattaimanji. According to the Kelly's Ratio values, $21 \%$ of the samples $(16,17,19,23,25,30$ and 31) come under low sodium content category and the remaining $79 \%$ of the samples $(1,2,3,4,5,6,7,8,9,10,11,12,13,14,15,18,20,21,22,24,26,27,28,29,30$, 31,32 and 33) come under high sodium content category. According to Kelly's Ratio, the majority of the groundwater samples in the study area fall under unsuitable for irrigation.

For agriculture development in the study area, irrigation suitability was evaluated from total hardness, sodium adsorption ratio, chloride bicarbonate ratio, permeability index and Kelley's ratio and the results of the analysis are presented in Table-5. 
RASĀYAN J. Chem.

Vol. 11 | No. 2 |806 - 818 | April - June | 2018

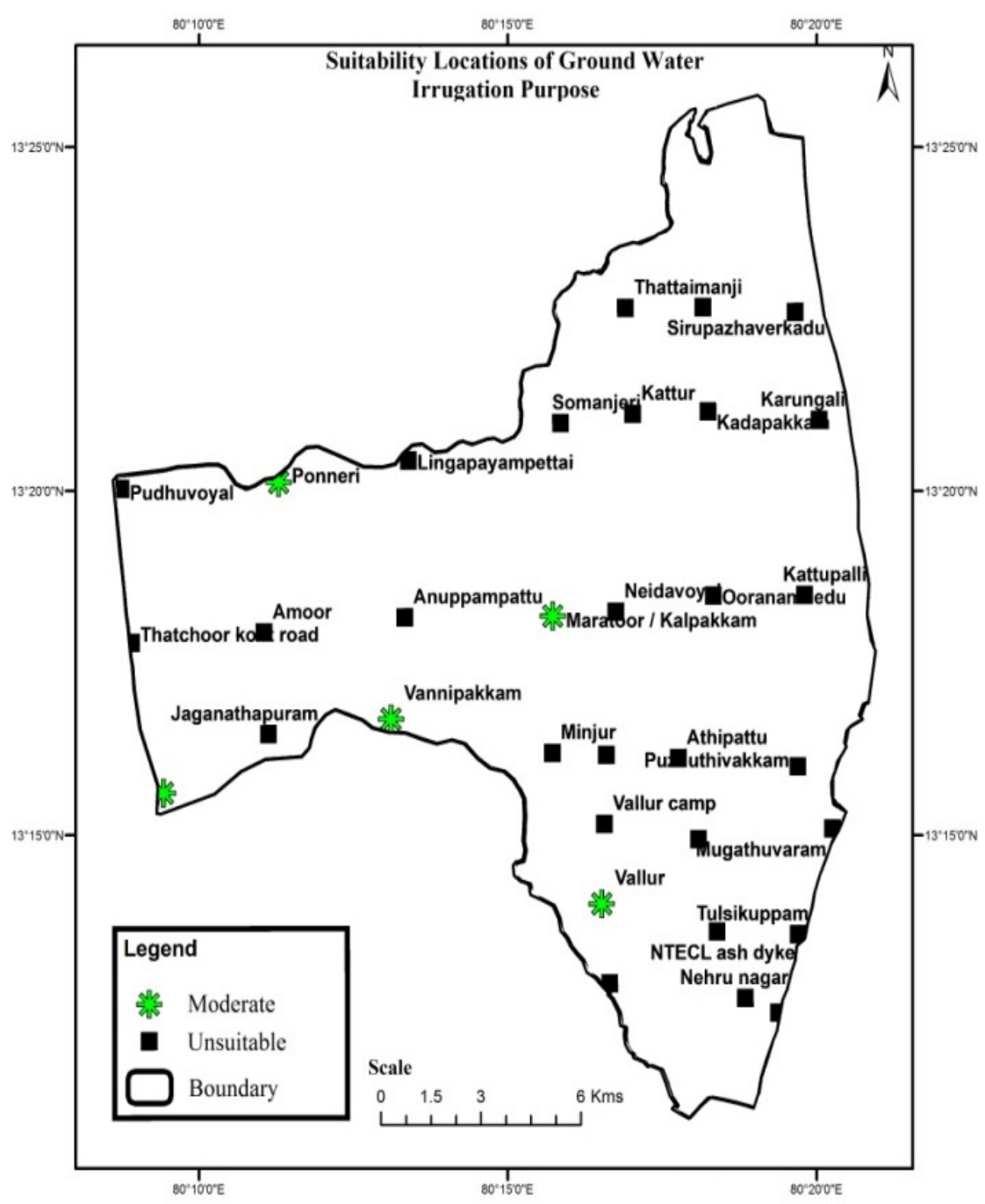

Fig.-3: Locations of groundwater suitable for irrigation purposes

Figure-3 shows the suitability of groundwater of the study area for irrigation purpose. The interpolated map shows that groundwater of the villages is falling in moderate category and bad category limit for irrigation purpose. Villages falling in moderately suitable for irrigation category are Vallur, Marattor/Kalpakkam, Vannipakkam, Ponneri and Janappanchathiram koot road. Other villages come under the bad category. The main reason for the unsuitability for irrigation purpose is the presence of sodium in the groundwater by salinity intrusion.

\section{CONCLUSION}

Unplanned urbanization, industrialization, agricultural development, over-extraction of groundwater and poor water management practices are causing water quality deterioration in the coastal areas of Chennai. Groundwater samples were collected, analyzed and evaluated with respect to distance from the sea coast. It was found that groundwater of the study area is not falling in the desirable category for drinking. Samples in the Northern and Eastern part show that they are unsuitable for dinking. The study reveals that sodium content in most of the groundwater samples is high and hence unsuitable for irrigation. The main reason is saline water intrusion in the coastal area. The present study indicates that sea water intrusion has occurred with reference to distance from the sea coast. Impact of Pulicat Lake, Buckingham canal and 
anthropogenic activities by industries in the study area are also influencing the extent of salinity in the groundwater. It can be controlled by minimizing the overpumping and recharging groundwater through rainwater harvesting. The present study of hydrogeochemistry recommends the importance of regular monitoring and proper management of existing fresh groundwater resources for domestic and irrigation purposes.

\begin{tabular}{|c|c|c|c|c|c|c|c|c|c|}
\hline \multicolumn{2}{|c|}{$\mathrm{TH}$} & \multicolumn{2}{|r|}{ SAR } & \multicolumn{2}{|c|}{ CBR } & \multicolumn{2}{|c|}{ PI } & \multicolumn{2}{|c|}{ K R } \\
\hline Criteria & $\begin{array}{c}\text { No of } \\
\text { sample } \\
\text { s and } \% \\
\text { age }\end{array}$ & Criteria & $\begin{array}{c}\text { No of samples } \\
\text { and } \\
\text { Percentage }\end{array}$ & Criteria & $\begin{array}{c}\text { No of samples } \\
\text { and } \\
\text { Percentage }\end{array}$ & Criteria & $\begin{array}{c}\text { No of } \\
\text { samples } \\
\text { and } \\
\text { Percentage }\end{array}$ & Criteria & $\begin{array}{c}\text { No of } \\
\text { samples } \\
\text { and\%age }\end{array}$ \\
\hline $\begin{array}{c}\text { Excelle } \\
\text { nt } \\
<300\end{array}$ & $\begin{array}{c}18 \\
(55 \%)\end{array}$ & $\mid \begin{array}{c}\text { Excellent } \\
<10\end{array}$ & $3(9 \%)$ & \multirow{3}{*}{$\leq 2$ Good } & \multirow{3}{*}{$26(79 \%)$} & $\begin{array}{l}\text { Class I } \\
(\geq 75 \%) \\
\text {-Good }\end{array}$ & $18(55 \%)$ & \multirow{3}{*}{$\begin{array}{l}\leq 1- \\
\text { Good }\end{array}$} & \multirow{3}{*}{$7(21 \%)$} \\
\hline $\begin{array}{c}\text { Good } \\
300 \text { to } \\
400\end{array}$ & $\begin{array}{c}5 \\
(15 \%)\end{array}$ & $\begin{array}{c}\text { Good } 10 \\
\text { to } 18\end{array}$ & $8(24 \%)$ & & & \multirow{2}{*}{$\begin{array}{c}\text { Class II } \\
\text { (between } \\
25 \% \text { and } \\
75 \% \text { )- } \\
\text { Moderate }\end{array}$} & \multirow{2}{*}{$15(45 \%)$} & & \\
\hline $\begin{array}{l}\text { Medium } \\
400 \text { to } \\
500 \\
\end{array}$ & $\begin{array}{c}4 \\
(12 \%)\end{array}$ & $\begin{array}{l}\text { Medium } \\
18 \text { to } 26\end{array}$ & $3(9 \%)$ & & & & & & \\
\hline $\begin{array}{c}\text { Bad } 500 \\
\text { to } 600\end{array}$ & $\begin{array}{c}1 \\
(3 \%)\end{array}$ & $\begin{array}{l}\mathrm{Bad} \\
>26\end{array}$ & $19(58 \%)$ & \multirow[t]{2}{*}{$\begin{array}{l}>2 \\
\mathrm{Bad}\end{array}$} & \multirow[t]{2}{*}{$7(21 \%)$} & \multirow{2}{*}{$\begin{array}{c}\text { Class III } \\
(\leq 25 \%)- \\
\text { Bad }\end{array}$} & & \multirow{2}{*}{$\begin{array}{l}>1- \\
\text { Bad }\end{array}$} & \multirow{2}{*}{$26(79 \%)$} \\
\hline $\begin{array}{c}\text { Very } \\
\text { bad } \\
>600\end{array}$ & $\begin{array}{c}4 \\
(12 \%)\end{array}$ & $\mid \begin{array}{c}\text { Very bad } \\
>26\end{array}$ & 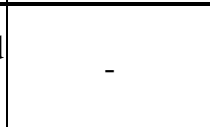 & & & & & & \\
\hline
\end{tabular}

\section{ACKNOWLEDGMENT}

The authors express their sincere thanks to Scientist Dr.L. Stanley Abraham, Sathyabama Institute of Science and Technology for his support in analyzing the groundwater samples. The authors also wish to thank Mr.Parthiban. S and Mr.Pushparaj. S, Sathyabama Institute of Science and Technology for their theoretic help. At last, authors want to thank anonymous reviewers for their useful comments on the manuscript.

\section{REFERENCES}

1. S. Selvam, R. Iruthaya Jeba Dhana Mala and V. Muthukakshmi, South India International Journal of Advanced Engineering Applications, 2(3), 25 (2013)

2. A. PonniahRaju, Dr.N. Chandrasekarand S. Saravanan, International Journal of Water Research, 1, 1 (2013)

3. D. Gnanasundarand L. Elango, Indian Journal of Environmental Protection, 18(10), 752 (1998)

4. MadhaviGanesan and Thayumanavan, J. Sustainable Development, 2(1), 94 (2009)

5. B. PrabhuDassBatvari and V.E. N. Mariappan, Rasayan J. Chem, 9(3), 424 (2016)

6. APHA Standard Methods for the Examination of Water and Wastewater, $21^{\text {st }}$ Ed., American Public Health Association, New York, USA (2005)

7. WHO Guidelines for Drinking Water Quality, Vol. 1, Recommendations $3^{\text {rd }}$ edn. WHO, Geneva, 515 (2004)

8. Indian Standard, Drinking Water-Specification (Second Revision), IS $10500: 2012$ (2012)

9. K.R. Karanth, Groundwater Assessment Development and Management, 610 (1987)

10. LA. Richards, Diagnosis and Improvement of Saline and Alkali Soils, USDA handbook, 160, 60 (1954) 
RASĀYAN J. Chem.

Vol. 11 | No. 2 |806-818 | April - June | 2018

11. L.D. Doneen, Notes on Water Quality in Agriculture, Water Science and Engineering, University of California (1964)

12. W.P. Kelley, S.M. Brownand G.I. Jr. Leibig, Soil Science, 49, 95 (1940)

13. K. Srinivasamoorthy, M. Vasanthavigar, K. Vijayaraghavan, R. Sarathidasan and S. Gopinath, Arab J. Geosci, 1 (2011), DOI: 10.1007/s12517-011-0351-2

14. M.N. Tijani, Environmental Geology, 24, 194 (1994)

15. A. Saleh, F. Al-Ruwaih and M. Shehata, J. Arid Environ., 42, 195 (1999)

16. S. Venkateswaran and S. Vediappan, International Journal of Innovative Technology and Exploring Engineering, 3, 2 (2013)

17. R.J. Desai, S.K. Gupta and M.V. Shah, Hydrol. Science Bull., 24, 71 (1979)

18. N. Janardhana Raju, Env. Geol., 52, 1067(2007)

19. R. Ayyandurai, M. Suresh and S. Venkateswaran, International Journal of Innovative Technology and Exploring Engineering, 2, 3 (2013)

[RJC-1991/2017] 